\title{
De statutaire procuratiehouder nader beschouwd
}

\author{
Mr. W.J.M. Jansen en mr. W.J. Dam*
}

\begin{abstract}
In deze bijdrage gaan de auteurs in op de vraag in hoeverre titel $3.3 \mathrm{BW}$ van toepassing is op de statutaire procuratiehouder, daarbij trachtend een volledig overzicht te creëren. Hiermee wordt voor het eerst een volledig onderzoek gedaan naar de analoge toepasbaarbeid van titel $3.3 \mathrm{BW}$ op de statutaire procuratiehouder.
\end{abstract}

\section{Inleiding}

In de literatuur bestaat verdeeldheid over de vraag hoe een statutaire procuratiehouder gekwalificeerd moet worden. ${ }^{1}$ De heersende leer is dat de statutaire procuratiehouder geen gevolmachtigde is in de zin van titel $3.3 \mathrm{BW}{ }^{2}$ Sommige auteurs vinden de statutaire procuratiehouder echter wel een gevolmachtigde, daarbij geen acht slaande op de statutaire grondslag van de vertegenwoordigingsbevoegdheid. ${ }^{3}$ Veel auteurs geven aan dat de kwalificatie niet uitmaakt, omdat titel 3.3 BW hoe dan ook (grotendeels) van toepassing is door de schakelbepalingen van de artikelen 3:78 en 3:79 BW. Een volledig onderzoek naar de toepasselijkheid van titel $3.3 \mathrm{BW}$ op de statutaire procuratiehouder is echter tot op heden niet uitgevoerd. Met deze bijdrage willen wij voorzien in deze leemte. De uitkomst van het onderzoek is onder meer relevant om te weten hoe een wederpartij beschermd wordt tegen onbevoegd handelen, aan welke grenzen de bevoegdheid van een procuratiehouder gebonden is, en hoe en wanneer de procuratie eindigt.

In deze bijdrage gaan wij in op twee vragen. De eerste vraag is of de statutaire procuratiehouder een gevolmachtigde is in de zin van titel 3.3 BW. Wij menen dat dit niet het geval is. Dit werpt de vervolgvraag op in hoeverre titel 3.3 BW van toepas-

Mr. W.J.M. Jansen is kandidaat-notaris bij De Brauw Blackstone Westbroek te Amsterdam. Mr. W.J. Dam is kandidaat-notaris bij De Brauw Blackstone Westbroek te Amsterdam.

1. Zie bijv. Asser/Kramer \& Verhagen 10-III 2015/56; P. Vlas, Rechtspersonen (Praktijkreeks IPR, deel 9), Apeldoorn: Maklu 2017/297; Asser/ Van der Grinten \& Maeijer 2-II 1997/86; W.C.L. van der Grinten, Van der Heijden. Handboek voor de naamloze en de besloten vennootschap, Zwolle: W.E.J. Tjeenk Willink 1992/236; Van Solinge, in: T\&C Burgerlijk Wetboek, art. 10:117 BW, aant. 3.

2. Asser/Van Solinge \& Nieuwe Weme 2-IIb 2019/161; Asser/Maeijer \& Kroeze 2-I* 2015/332; P.J. Dortmond, Van der Heijden/Van der Grinten. Handboek voor de naamloze en besloten vennootschap, Deventer: Kluwer 2013/236; P.H.N. Quist, Procuratieperikelen (II slot), WPNR 2005, afl. 6628, p. 563; G.C. van Eck, De substitutiebevoegdheid van de statutaire procuratiehouder, V\&O 2009, afl. 3, p. 59.

3. Vgl. Asser/Kramer \& Verhagen 10-III 2015/56, met verdere verwijzingen. sing is op de statutaire procuratiehouder. Wij sluiten af met een conclusie. De statutaire procuratiehouder is de procuratiehouder die zijn of haar vertegenwoordigingsbevoegdheid ontleent aan de statuten. ${ }^{4}$

\section{Gevolmachtigde of functionaris?}

\subsection{Grondslag}

De heersende leer is dat de statutaire procuratiehouder een bijzondere functionaris is en geen gevolmachtigde. In de literatuur wordt op de onderbouwing hiervan slechts op summiere wijze ingegaan. ${ }^{5}$ Een aantal argumenten voor de statutaire procuratiehouder als bijzondere functionaris is af te leiden uit de wetssystematiek. Zo bepaalt artikel 2:5 BW dat de kapitaalvennootschap, zijnde een rechtspersoon, dezelfde bevoegdheden heeft als een natuurlijk persoon ten aanzien van het vermogensrecht. Daaruit kan reeds worden afgeleid dat de vennootschap ook bevoegd is om een volmacht te verlenen. Artikel 2:130/240 lid $4 \mathrm{BW}$, waaruit volgt dat men in de statuten een statutaire procuratiehouder kan aanwijzen, zou overbodig zijn indien de statutaire procuratiehouder als gevolmachtigde is bedoeld.

Een ander argument op grond van de wetssystematiek is dat de grondslag voor de vertegenwoordigingsbevoegdheid van de statutaire procuratiehouder in Boek 2 BW ligt en niet in Boek $3 \mathrm{BW}$. Als het voorgaande wordt geplaatst in het licht van de gelaagde structuur van het BW, ${ }^{6}$ blijkt dat de grondslag van de vertegenwoordigingsbevoegdheid van de statutaire procuratiehouder niet in het vermogensrecht ligt en dus geen volmacht is in de zin van titel $3.3 \mathrm{BW}$.

In het verlengde van het vorige argument ligt de opvatting van Kroeze. Hij meent dat de statutaire procuratiehouder zijn of haar bevoegdheid ontleent aan zijn of haar statutaire positie. De statutaire inrichting van de vennootschap brengt dus met zich dat de statutaire procuratiehouder vertegenwoordigingsbevoegd is op grond van de statuten en niet op grond van een volmacht. ${ }^{7}$ Ook Kroeze lijkt zijn standpunt te ontlenen aan de

\footnotetext{
4. Zie voor de praktische invulling hiervan C.J. Groffen, Vertegenwoordiging door een procuratiehouder, V\&O 1995, p. 83-84.

5. Vgl. noot 3 .

6. C.J. van Zeben \& J.W. du Pon, Parlementaire geschiedenis van het Nieuwe Burgerlijk Wetboek. Algemeen deel, Deventer: Kluwer 1962, p. 133-134.

7. Asser/Maeijer \& Kroeze 2-I* 2015/332.
} 


\section{Maandblad}

Ondernemingsrecht

plaats waar de bevoegdheid gevonden kan worden, namelijk in de statuten die door Boek 2 BW beheerst worden.

Verder wijzen wij op de parlementaire geschiedenis bij artikel 10:117 onder b BW. Daarin wordt aangegeven dat de procuratiehouder die zijn bevoegdheid aan de statuten ontleent, een functionaris in de zin van dit artikel is en daarom onderworpen is aan het incorporatierecht. ${ }^{8}$ Dit is een genuanceerder standpunt dan werd ingenomen in de toelichting bij de voorganger van dit wetsartikel, zoals opgenomen in de Wet conflictenrecht corporaties. Daarin werd ervan uitgegaan dat iedere procuratiehouder, dus ook die krachtens volmacht, als functionaris diende te worden gezien. ${ }^{9}$

\subsection{Bevoegdheidsverdeling}

Twee andere argumenten voor de heersende leer dat de statutaire procuratiehouder een bijzondere functionaris is, kan men vinden in de verdeling van de bevoegdheden tussen de algemene vergadering en het bestuur. Niet ter discussie staat dat een vennootschap ook krachtens volmacht kan worden vertegenwoordigd. Het verlenen van een volmacht is een rechtshandeling. ${ }^{10}$ De verrichting van deze rechtshandeling valt uiteen in twee aspecten: (1) een intern proces van wilsvorming, de besluitvorming, en (2) een extern handelen met de wederpartij van de rechtspersoon, de vertegenwoordiging. ${ }^{11}$

Het eerste argument ligt in de besluitvorming. Het besluit tot wijziging van de statuten, en daarmee de interne beslissingsbevoegdheid om een statutaire procuratiehouder aan te wijzen, ligt bij de algemene vergadering (art. 2:121/231 lid $1 \mathrm{BW}$ ) en niet bij het bestuur. ${ }^{12}$ Als men de bevoegdheid van de procuratiehouder ziet als een volmacht, betekent dit dat een volmacht zou worden gegeven door de algemene vergadering. Daarmee overschrijdt de algemene vergadering de grenzen van haar bevoegdheid. ${ }^{13}$ Door de statutaire procuratie te zien als een aparte vennootschapsrechtelijke vertegenwoordigingsfiguur kan men het bovenstaande verklaren.

Het tweede argument vindt men in het externe handelen. De daadwerkelijke verlening van de bevoegdheid aan de procuratiehouder geschiedt volgens Van Eck indirect door de algemene vergadering bij het wijzigen van de statuten. ${ }^{14}$ Uit de hoofdregels van vertegenwoordiging volgt nu juist dat het bestuur vertegenwoordigingsbevoegd is om volmachten af te

8. Kamerstukken II 2009/10, 32137, nr. 3, p. 67

9. Kamerstukken II 1994/95, 24141, nr. 3, p. 15.

10. Asser/Kortmann 3-III 2017/22.

11. Annotatie Blanco Fernández bij HR 19 oktober 2001, ECLI:NL:HR: 2001:ZC3647, JOR 2002/1, r.o. 3.4.4; zie ook Asser/Van Solinge \& Nieuwe Weme 2-IIb 2019/160.

12. Het feit dat het bestuur in de praktijk vaak het voorstel tot wijziging doet, maakt dit niet anders.

13. HR 21 januari 1955, ECLI:NL:HR:1955:AG2033, NJ 1959/43 (Forumbank); zie ook J.M. de Jongh, Tussen societas en universitas (diss. Rotterdam), Deventer: Kluwer 2014, p. 320-322.

14. Van Eck 2009, p. 60.

15. Van der Heijden/Van der Grinten/Dortmond 2013/236. geven, niet de algemene vergadering. ${ }^{15}$ Hieruit volgt dat het bij de statutaire procuratiehouder niet om een volmacht gaat.

Ook als de statuten een grondslag bevatten voor de benoeming van een statutaire procuratiehouder door het bestuur, wordt het voorgaande niet anders. Deze statutaire grondslag voor benoeming van een statutaire procuratiehouder moet worden gezien als een verlening van een bevoegdheid aan het bestuur. ${ }^{16}$ Of de toekenning van vertegenwoordigingsbevoegdheid in dat geval wordt aangemerkt als het verlenen van een volmacht of het toekennen van de functie van statutaire procuratiehouder, zal afhangen van de uitleg van het relevante besluit. ${ }^{17}$ Als uit het besluit blijkt dat de statuten worden gebruikt als grondslag voor de verlening van de vertegenwoordigingsbevoegdheid, dan is sprake van een statutaire procuratiehouder.

\section{Analoge toepassing titel $3.3 \mathrm{BW}$ : introductie}

\subsection{Analoge toepasbaarheid: academische vrijheid}

Een aantal auteurs is van mening dat de kwalificatie van de procuratiehouder weinig praktische betekenis heeft vanwege de schakelbepalingen van de artikelen 3:78 en 3:79 BW. ${ }^{18}$ Door deze artikelen kan een gedeelte van titel 3.3 BW analoog worden toegepast op de statutaire procuratiehouder als deze procuratiehouder niet als gevolmachtigde wordt gezien. In deze paragraaf zullen wij per artikel onderzoeken in hoeverre deze veronderstelling juist is. ${ }^{19}$

Artikel 3:78 BW biedt duidelijkheid over welke bepalingen uit titel $3.3 \mathrm{BW}$ in ieder geval van toepassing zijn op vermogensrechtelijke vertegenwoordigingshandelingen die worden verricht uit anderen hoofde dan volmacht, en dus van toepassing zijn op de statutaire procuratiehouder. Genoemd worden de artikelen 3:63 lid 1, 3:66 lid 1, 3:67, 3:69, 3:70, 3:71 en 3:75 lid 2 BW. Uit de parlementaire geschiedenis blijkt echter dat analoge toepassing van andere wetsartikelen uit titel 3.3 BW niet wordt uitgesloten, maar dat de uitwerking hiervan wordt overgelaten aan de wetenschap en de rechtspraak. ${ }^{20}$

16. Immers, deze specifieke bevoegdheid wordt niet door de wet geregeld, waardoor sprake is van een restbevoegdheid van de algemene vergadering in de zin van art. 2:107/217 lid 1 BW. Deze restbevoegdheid kan worden ingevuld naar eigen inzicht van de algemene vergadering.

17. Bestuursbesluiten moeten naar objectieve maatstaven worden uitgelegd; concl. A-G Timmerman, ECLI:NL:PHR:2010:BN8533, bij HR 26 november 2010, NJ 2011/55 m.nt. P. van Schilfgaarde (Silver Lining Finance/Perstorp).

18. Zie o.a. Asser/Van Solinge \& Nieuwe Weme 2-IIb 2019/161; Asser/ Maeijer \& Kroeze 2-I* 2015/332; Quist 2005.

19. Art. 3:79 BW bepaalt dat titel $3.3 \mathrm{BW}$ ook van toepassing kan zijn op niet-vermogensrechtelijke rechtshandelingen. $\mathrm{Nu}$ de procuratiehouder hier (nagenoeg) nooit mee te maken zal krijgen, laten we de analoge toepassing op grond van dit artikel onbesproken.

20. C.J. van Zeben \& J.W. Du Pon, Parlementaire geschiedenis van het Nieuwe Burgerlijk Wetboek. Invoeringswet Boek 3, Deventer: Kluwer 1981, p. 303-304 (MvA II). 


\subsection{Definitiebepalingen en vorm ${ }^{21}$}

Voor toepassing van titel $3.3 \mathrm{BW}$ wordt onder rechtshandeling ook het in ontvangst nemen van een verklaring begrepen, zo blijkt uit artikel 3:60 lid $2 \mathrm{BW}$. Het is nuttig om te onderzoeken of deze bepaling analoog kan worden toegepast op de statutaire procuratiehouder. Het komt hierbij neer op de vraag of de statutaire procuratiehouder bevoegd is om namens de vennootschap verklaringen in ontvangst te nemen: kan bijvoorbeeld afstand van recht worden gedaan jegens de vennootschap door dit te verklaren aan de statutaire procuratiehouder? ${ }^{22}$

Wij beantwoorden deze vraag bevestigend. Artikel 3:60 lid 2 $\mathrm{BW}$ is in de wet opgenomen om onzekerheid over de kwalificatie van het 'in ontvangst nemen' van een verklaring te voorkomen. ${ }^{23}$ Evenwel maakt het praktisch waarschijnlijk geen verschil als dit artikellid niet wordt toegepast op de statutaire procuratiehouder, en de statutaire procuratiehouder eventueel dus niet bevoegd is om verklaringen in ontvangst te nemen. Immers, als een verklaring wordt gedaan jegens de statutaire procuratiehouder, is de kans aanmerkelijk dat de verklarende partij ofwel al eerder contact heeft gehad met de vennootschap door middel van de statutaire procuratiehouder, ofwel door gedragingen van de statutaire procuratiehouder mocht aannemen dat deze bevoegd was verklaringen voor de vennootschap in ontvangst te nemen. Er zal dan sprake zijn van schijn van vertegenwoordigingsbevoegdheid, hetgeen voor risico moet komen van de vennootschap (art. 3:37 lid 3 jo. art. 3:61 lid $2 \mathrm{BW}){ }^{24}$

Een volmacht kan vormvrij worden verleend volgens artikel 3:61 lid 1 BW. Deze bepaling kan niet worden toegepast op de statutaire procuratiehouder. De statutaire procuratiehouder ontleent zijn of haar bevoegdheid aan de statuten en kan daarom niet vormvrij worden benoemd.

\section{Bescherming wederpartij}

\subsection{Schijn van vertegenwoordiging}

Artikel 3:61 lid 2 BW ziet op de schijn van volmacht, opgewekt door toedoen van de 'volmachtgever'. Ook de vennootschap kan de schijn opwekken dat de procuratiehouder een gevolmachtigde is. De vraag rijst daarmee of de vennootschap ook de schijn kan opwekken dat sprake is van een statutaire procuratiehouder. Artikel 2:6 lid $4 \mathrm{BW}$ jo. artikel 22 lid 1 onder b Handelsregisterbesluit 2008 bepaalt dat de procura-

21. Art. 3:60 lid $1 \mathrm{BW}$ is een definitiebepaling van de volmacht en derhalve niet van toepassing op de procuratiehouder.

22. Vgl. HR 28 november 2014, ECLI:NL:HR:2014:3460, NJ 2016/90 m.nt. H.J. Snijders.

23. Asser/Kortmann 3-III 2017/20.

24. Vgl. HR 3 november 1995, ECLI:NL:HR:1995:ZC1872, NJ 1996/123 (Apollo Hotel/Kilawy); HR 1 november 1991, ECLI:NL:HR: 1991:ZC0391, NJ 1992/623 (H/Tilburgsche Hypotheekbank); Hof Arnhem 18 april 2000, ECLI:NL:GHARN:2000:AD4277, NJ 2001/426; Hof Arnhem-Leeuwarden 14 oktober 2014, ECLI:NL:GHARL:2014:7861. tiehouder en de omvang van zijn of haar bevoegdheid moeten worden ingeschreven in het handelsregister. Desondanks bewijst de praktijk dat de vennootschap deze schijn wel kan opwekken. ${ }^{25}$ Het gaat dan om gevallen waarin de vennootschap doet voorkomen dat de statuten een grondslag bevatten voor de vertegenwoordigingsbevoegdheid, terwijl dit niet zo is. Analoge toepassing van artikel 3:61 lid 2 BW is dus ons inziens mogelijk.

Als een beperking in een volgens wet of gebruik openbaar gemaakte volmacht dusdanig ongebruikelijk is dat een wederpartij die niet hoeft te verwachten, kan deze beperking niet aan die wederpartij worden tegengeworpen, zo blijkt uit artikel 3:61 lid 3 BW. Dit dient te worden gezien als een uitzondering op de werking van artikel 2:6 lid $4 \mathrm{BW} .^{26}$ Een voorbeeld van een ongebruikelijke beperking, genoemd in de parlementaire geschiedenis, is een bijzonder lage financiële limiet van een gevolmachtigde. ${ }^{27} \mathrm{Wij}$ zien geen enkel bezwaar tegen toepassing van dit artikellid op de statutaire procuratiehouder. $^{28}$ Ook een statutaire procuratiehouder kan immers op dusdanig ongebruikelijke wijze in zijn of haar bevoegdheden worden beperkt dat de wederpartij dit niet hoeft te verwachten. ${ }^{29}$ Ook wordt de bevoegdheid van de statutaire procuratiehouder krachtens wet ingeschreven in het handelsregister.

\subsection{Bescherming bij einde vertegenwoordigingsbevoegdheid}

De bescherming van de wederpartij bij het einde van een volmacht wordt geregeld in artikel 3:76 BW. Daarnaast roept het artikel een schadevergoedingsplicht in het leven bij misbruik van gebrekkige kennis van de derde. Artikel 2:6 BW bevat strengere regels dan artikel 3:76 lid $1 \mathrm{BW}$ in situaties waarin een wijziging in de statuten, zijnde de grondslag voor de bevoegdheid van de statutaire procuratiehouder, kan worden tegengeworpen aan derden. Indien en voor zover een procuratie dus vanwege een statutenwijziging eindigt, kan artikel 3:76 lid $1 \mathrm{BW}$ geen toepassing vinden. Een statutaire procuratie eindigt door statutenwijziging indien (1) de statutaire procuratiehouder bij naam was genoemd in de statuten en deze naam wordt geschrapt, of (2) de grondslag voor de procuratie geheel wordt verwijderd uit de statuten. Kan artikel 3:76 lid 1 $\mathrm{BW}$ dan wel toepassing vinden indien de procuratie eindigt zonder statutenwijziging? Dus indien alleen de individuele

25. Vgl. HR 12 januari 2001, ECLI:NL:HR:2001:AA9429, NJ 2001/157 (Kuypers/Wijnveen); zie ook P.J. van der Korst, Onbevoegde vertegenwoordiging, apparent authority en de verwaarloosde betekenis van het handelsregister. Artikel 3:61 leden 2 en 3 BW herbeschouwd voor rechtspersonen, in: S.C.J.J. Kortmann e.a. (red.), Onderneming en 10 jaar nieuw burgerlijk recht, Deventer: Kluwer 2002, p. 149-150.

26. Van der Korst 2002, p. 154-164.

27. Van Zeben \& Du Pon 1981, p. 1180 (MvT).

28. Overigens kom je niet toe aan toepassing van art. 3:61 lid $3 \mathrm{BW}$ als de heersende leer met betrekking tot art. 2:130/240 lid 3 BW, zoals nader beschreven in par. 6 .

29. Vgl. concl. A-G Timmerman, ECLI:NL:PHR:2008:BD7598, bij HR 26 september 2008, JOR 2008/331 m.nt. P.J. van der Korst, met verdere verwijzingen. 


\section{Maandblad}

Ondernemingsrecht

vertegenwoordigingsbevoegdheid van de procuratiehouder eindigt?

Wij zouden willen aannemen van wel. Indien de beëindiging van de procuratie is ingeschreven in het handelsregister, kan artikel 3:76 lid $1 \mathrm{BW}$ in zoverre analoog worden toegepast dat de bekendmaking in het handelsregister valt onder artikel 3:76 lid 1 onder a BW. Het einde van de procuratie is dan immers bekendgemaakt op een wijze die krachtens de wet en anders in ieder geval krachtens de verkeersopvattingen meebrengt dat dit aan derden kan worden tegengeworpen. Analoge toepassing is onmogelijk als het einde van de procuratie an sich niet wordt ingeschreven in het handelsregister: artikel 2:6 lid 3 BW vindt dan toepassing. ${ }^{30}$

Artikel 3:76 lid 2 BW bevat een schadevergoedingsregeling voor het geval een situatie als bedoeld in lid 1 zich voordoet. Het bevat daarbij een uitzondering voor de situatie dat de gevolmachtigde niet wist of behoorde te weten dat zijn of haar volmacht is geëindigd. Lid 2 kan alleen analoog worden toegepast als lid 1 ook is toegepast. Uit de parlementaire geschiedenis blijkt dat lid 2 een lex specialis is van artikel 3:70 BW, specifiek opgenomen voor de gevolmachtigde. ${ }^{31}$ Artikel 3:70 BW is wel van toepassing op de statutaire procuratiehouder op grond van artikel 3:78 BW. Ten opzichte van artikel 3:70 BW lijkt de enige toegevoegde waarde van artikel 3:76 lid 2 BW de uitzondering uit de tweede volzin te zijn. Daarin is bepaald dat de gevolmachtigde niet verplicht is tot schadevergoeding indien hij of zij zelf niet wist of behoorde te weten dat de volmacht geëindigd was. Deze uitzondering lijkt overigens uiterst zeldzaam in haar toepasbaarheid. ${ }^{32}$ De bewijslast rust dan ook op de gevolmachtigde. ${ }^{33}$ Gelet op het voorstaande, alsmede het feit dat de wetgever ervoor heeft gekozen om artikel 3:70 BW wel analoog toepasselijk te verklaren, maar artikel 3:76 lid 2 BW niet, zouden wij willen aannemen dat analoge toepasbaarheid van artikel 3:76 lid $2 \mathrm{BW}$ onmogelijk is. ${ }^{34} \mathrm{Zij}$ is ook waarschijnlijk onnodig, omdat in een dergelijke situatie aansprakelijkheid kan ontstaan uit onrechtmatige daad. ${ }^{35}$

\section{Toerekening van kennis}

\subsection{Babbel-criterium}

Kennis kan worden toegerekend in de verhouding tussen volmachtgever en gevolmachtigde met betrekking tot de beoordeling van de geldigheid van een rechtshandeling. Dit houdt in dat de kennis van de volmachtgever aanwezig kan worden

30. Zie hierover Asser/Maeijer \& Kroeze 2-I* 2015/343 en HR 26 maart 2004, ECLI:NL:HR:2004:AO2779, NJ 2004/330 (Zohar/De Poel).

31. Van Zeben \& Du Pon 1981, p. 301 (MvA II).

32. Vgl. Asser/Kortmann 3-III 2017/95.

33. Van Zeben \& Du Pon 1981, p. 301-302 (MvA II).

34. Vgl. Asser/Kortmann 3-III 2017/98

35. HR 1 juli 1976, ECLI:NL:HR:1976:AB6866, NJ 1976/496; HR 31 januari 1997, ECLI:NL:HR:1997:ZC2266, NJ 1998/704 (De Slingerij/Provincie Groningen). geacht bij de gevolmachtigde en vice versa. Dit blijkt uit artikel 3:66 lid 2 BW.

De eerste vraag die rijst, is of analoge toepassing van artikel 3:66 lid 2 BW überhaupt nodig is om kennis van de statutaire procuratiehouder aan de vennootschap toe te rekenen. Kan niet simpelweg worden volstaan met het Babbelcriterium, ${ }^{36}$ al dan niet aangevuld met de verkeersopvattingen? ${ }^{37}$ Het antwoord luidt waarschijnlijk bevestigend.

Hoewel artikel 3:66 lid 2 BW lang niet altijd noodzakelijk zal zijn voor de toerekening van kennis van de statutaire procuratiehouder aan de vennootschap, biedt analoge toepassing daarvan wel duidelijkheid. De Hoge Raad stelt twee eisen voor een analoge toepassing van artikel 3:66 lid 2 BW op andere verhoudingen: (1) dat zij plaatsvindt in een verhouding die soortgelijk is aan de verhouding die bestaat tussen een volmachtgever en de gevolmachtigde, en (2) dat die vertegenwoordiger in zijn of haar hoedanigheid handelt met een derde die een beroep doet op de toerekening van die kennis. ${ }^{38}$

\subsection{Toepassing}

Aan de eerste eis van de Hoge Raad kan in algemene zin invulling worden gegeven. ${ }^{39}$ Hoewel de exacte betekenis van de eis ongewis blijft, lijkt het ons zeer waarschijnlijk dat de statutaire procuratiehouder hieraan voldoet. Wij hebben hierboven namelijk beschreven dat de verhouding tussen de statutaire procuratiehouder en de vennootschap op veel punten sterk overeenkomt met de verhouding tussen gevolmachtigde en volmachtgever. Met Katan menen wij dat uit het arrest Ontvanger/Voorsluijs geen bezwaren blijken tegen analoge toepassing van artikel 3:66 lid 2 BW op functionarissen van de vennootschap. ${ }^{40}$ Statutaire procuratiehouders vallen hier ook onder, waardoor artikel 3:66 lid 2 BW kan worden toegepast op de verhouding tussen de statutaire procuratiehouder en de vennootschap.

36. HR 6 april 1979, ECLI:NL:HR:1979:AH8598, NJ 1980/34 m.nt. C.J.H. Brunner (Kleuterschool Babbel), nader uitgewerkt in HR 11 mei 1990, ECLI:NL:HR:1990:AC2014, NJ 1990/544 (Los Gauchos); HR 11 maart 2005, ECLI:NL:HR:2005:AR7344, NJ 2005/576; HR 11 november 2005, ECLI:NL:HR:2005:AT6018, NJ 2007/231 m.nt. J.B.M. Vranken (Ontvanger/Voorsluijs).

37. B.M. Katan, Toerekening van kennis aan rechtspersonen (diss. Nijmegen), Deventer: Wolters Kluwer 2017/5.6.3.

38. HR 11 november 2005, ECLI:NL:HR:2005:AT6018, NJ 2007/231 m.nt. J.B.M. Vranken (Ontvanger/Voorsluijs), r.o. 3.8; zie ook Katan 2017/7.5.2.

39. Op de tweede eis gaan wij hier niet nader in, omdat het hier om een zeer casuïstische eis gaat.

40. Katan 2017/7.5 (met verdere verwijzingen). Op de vraag of de procuratiehouder op dit vlak gelijk kan worden gesteld met de bestuurder gaan wij in deze bijdrage niet in, daar dit ons inziens geen effect heeft op de eventuele analoge toepassing van art. 3:66 lid 2 BW. Vgl. Katan 2017, p. 197-204. 


\section{Bevoegdheden ${ }^{41}$}

\subsection{Onbeperkte vertegenwoordigingsbevoegdheid}

Titel 3.3 BW bevat verschillende bepalingen die de bevoegdheden van de gevolmachtigde beperken. Wij noemen (1) artikel 3:62 BW, dat de bevoegdheid van de gevolmachtigde om daden van beschikking te verrichten beperkt, (2) artikel 3:64 $\mathrm{BW}$, dat de gevolmachtigde slechts onder drie omstandigheden de bevoegdheid geeft om zijn of haar volmacht weer aan een ander te verlenen (substitutie), en (3) artikel 3:68 BW, dat bepaalt dat de gevolmachtigde slechts als wederpartij van de volmachtgever mag optreden als de inhoud van de te verrichten rechtshandeling zo nauwkeurig vastligt dat strijd tussen beide belangen is uitgesloten (Selbsteintritt).

Het antwoord op de vraag in hoeverre de bovengenoemde bepalingen van overeenkomstige toepassing zijn op de statutaire procuratiehouder, hangt af van de toepasselijkheid van artikel 2:130/240 lid $3 \mathrm{BW}$ op de statutaire procuratiehouder. Deze artikelen bepalen dat de vertegenwoordigingsbevoegdheid van bestuurders onbeperkt en onvoorwaardelijk moet zijn. Artikel 2:130/240 lid 3 BW lijkt op het eerste gezicht niet van toepassing te zijn op de statutaire procuratiehouder. De heersende leer is echter dat artikel 2:130/240 lid 3 BW wél van toepassing is op de statutaire procuratiehouder, omdat artikel 2:130/240 lid $3 \mathrm{BW}$ conform de eerste EG-richtlijn moet worden uitgelegd. ${ }^{42}$

In de eerste EG-richtlijn ${ }^{43}$ wordt in artikel 9 lid 3 bepaald dat de beperking van vertegenwoordigingsbevoegdheid van het bestuur, wil deze externe werking krijgen, enkel mag bestaan uit vertegenwoordigingsbevoegdheid van een enkele persoon of meerdere, gezamenlijk handelende personen. De bedoeling bij het opstellen van deze bepaling is duidelijk: meer beperkingen op de vertegenwoordigingsbevoegdheid toelaten stuit op praktische bezwaren in het internationale handelsverkeer indien dit betekent dat van derden wordt verwacht dat zij telkens weer de statuten raadplegen van de vennootschap waarmee wordt gehandeld. ${ }^{44}$

Onder personen vallen onder de heersende leer ook statutaire procuratiehouders. In dat geval is er geen ruimte voor toepas-

41. Art. 3:63 lid 2 BW ziet op de volmachtverlening door een onbekwaam persoon. Een rechtspersoon kan niet onbekwaam zijn. Kortom, verlening van een procuratie door een onbekwame is niet mogelijk. De aard van de rechtsbetrekking tussen de procuratiehouder en de vennootschap verzet zich tegen de toepassing van art. 3:63 lid $2 \mathrm{BW}$.

42. E.E.G. Gepken-Jager, Vertegenwoordiging bij NV en BV (diss. Groningen), Deventer: Kluwer 2000, p. 303; J. Winter, J.B. Wezeman \& J. Schoonbrood, Van Schilfgaarde. Van de BV en de NV, Deventer: Wolters Kluwer 2017/55; J.B. Huizink, Rechtspersoon, vennootschap en onderneming (Studiereeks Burgerlijk Recht, deel 7), Deventer: Wolters Kluwer 2019, p. 236-237; Van Eck 2009. Anders: Asser/Van Solinge \& Nieuwe Weme 2-IIb 2019/161.

43. Eerste EG-richtlijn 68/151/EEG, PbEG 1968, L 65/8, d.d. 14 maart 1968. Thans Richtlijn (EU) 2017/1132 van het Europees Parlement en de Raad van 14 juni 2017 aangaande bepaalde aspecten van het vennootschapsrecht.

44. Kamerstukken II 1969/70, 10400, nr. 3, p. 5. sing van de artikelen 3:62, 3:64 en 3:68 BW. Een overeenkomstige toepassing zou immers strijd opleveren met artikel 2:130/240 lid $3 \mathrm{BW}$ omdat deze bepalingen een beperking van de bevoegdheid van de statutaire procuratiehouder zouden vormen.

\subsection{Beperkte vertegenwoordigingsbevoegdheid}

Indien men, in afwijking van de heersende leer, meent dat artikel 2:130/240 lid $3 \mathrm{BW}$ niet van toepassing is op de statutaire procuratiehouder, kan de vertegenwoordigingsbevoegdheid van de statutaire procuratiehouder op maat worden gemaakt. Gevolg hiervan is dat de artikelen 3:62, 3:64 en 3:68 BW analoge toepassing moeten vinden op de statutaire procuratiehouder. Overigens verdient deze route ons inziens de voorkeur, want dit maakt het mogelijk om de bevoegdheid van de statutaire procuratiehouder verdergaand op maat te snijden. Hierdoor zou de figuur van de statutaire procuratiehouder van toegevoegde waarde kunnen zijn ten opzichte van de andere vennootschapsrechtelijke functionarissen. ${ }^{45}$

Bij analoge toepassing van artikel 3:62 BW zal de statutaire procuratiehouder niet zomaar beschikkingsbevoegd zijn. De procuratie moet dat dan schriftelijk en ondubbelzinnig bepalen. Dit lijkt ons te passen bij de bevoegdheid van een vertegenwoordiger die niet onbeperkt en onvoorwaardelijk is.

Bij analoge toepassing van artikel 3:64 is het niet zomaar mogelijk voor de statutaire procuratiehouder om substitutie te verlenen. Ons inziens is analoge toepassing mogelijk. Ten eerste is het artikel van regelend recht. ${ }^{46}$ Hierdoor kan de vennootschap de substitutiebevoegdheid van de statutaire procuratiehouder volledig naar eigen wens inrichten. Als de vennootschap niets regelt, is aansluiting bij de bekende regeling van titel $3.3 \mathrm{BW}$ een overzichtelijk uitgangspunt, dat de vennootschap beschermt tegen ongebreidelde substitutie. Daar komt nog bij dat uit de parlementaire geschiedenis blijkt dat de gevolmachtigde jegens de volmachtgever een mededelingsplicht heeft als hij of zij overgaat tot substitutie. ${ }^{47}$ Hierdoor kan de volmachtgever dus tijdig beslissen of hij of zij het hiermee eens is. ${ }^{48}$ Toegepast op de statutaire procuratiehouder zou de vennootschap dus tijdig kunnen beslissen of zij het eens is met de door de statutaire procuratiehouder aangewezen persoon. Wij zien derhalve geen bezwaar tegen toepassing van artikel 3:64 BW op de statutaire procuratiehouder. Om de rechtszekerheid te vergroten doen wij de aanbeveling om de substitutiebevoegdheid nader te regelen in de statuten.

Analoge toepassing van artikel 3:68 BW zou betekenen dat de statutaire procuratiehouder niet namens de vennootschap met

45. Op de heersende leer is ons inziens ook wel een en ander af te dingen, nu de bedoeling achter art. 9 lid 3 van de eerste EG-richtlijn uit de jaren zestig stamt. Het was toen uiteraard significant omslachtiger om statuten van buitenlandse vennootschappen te raadplegen.

46. Hijma, in: T\&C Burgerlijk Wetboek, art. 3:64 BW, aant. 2.

47. Van Zeben \& Du Pon 1981, p. 272 (TM).

48. Vgl. nader A.C. van Schaick, Volmacht (Mon. BW nr. B5), Deventer: Kluwer 2011/22. 


\section{Maandblad}

Ondernemingsrecht

zichzelf kan handelen. Dit lijkt ons wederom passend voor een vertegenwoordiger wiens bevoegdheid niet onbeperkt en onvoorwaardelijk is.

Artikel 3:65 BW is een bepaling van regelend recht ${ }^{49}$ die is geschreven voor de situatie dat aan meerdere personen tezamen een vertegenwoordigingsbevoegdheid is verleend. Het artikel bepaalt dat als een volmacht aan een of meerdere personen tezamen is verleend, ieder van hen bevoegd is om zelfstandig te handelen. Deze situatie kan zich ook voordoen bij statutaire procuratiehouders. Voor statutaire procuratiehouders geldt volgens de heersende leer hetgeen in artikel 2:130/240 lid $3 \mathrm{BW}$ is bepaald en daardoor is artikel 3:65 BW overbodig. Indien men van mening is dat artikel 2:130/240 lid 3 BW niet van toepassing is op de statutaire procuratiehouder, lijkt artikel 3:65 $\mathrm{BW}$ een juist uitgangspunt.

\section{Beëindiging}

\subsection{Beëindigingsgronden}

Een andere voor de praktijk relevante vraag is wanneer de bevoegdheid van de statutaire procuratiehouder eindigt. Artikel 3:72 BW regelt het einde van de volmacht. Een volmacht eindigt:

a. door de dood, ondercuratelestelling of het faillissement van de volmachtgever of de toepassing van de schuldsanering op hem of haar;

b. door de dood, ondercuratelestelling of het faillissement van de gevolmachtigde of de toepassing van de schuldsanering op hem of haar, tenzij anders is bepaald;

c. door herroeping door de volmachtgever; en door opzegging door de gevolmachtigde.

Interessant is de vraag of dit artikel analoog van toepassing is op de statutaire procuratiehouder. Wij behandelen de verschillende beëindigingsgronden los van elkaar. De genoemde beëindigingsgronden verschillen namelijk wezenlijk, onder meer doordat een deel van regelend recht is.

Sub a is dwingendrechtelijk en bepaalt dat de volmacht eindigt in geval van de dood, ondercuratelestelling, faillissement of schuldsanering van de volmachtgever (bij analoge toepassing dus de rechtspersoon). Het ligt voor de hand dat de dood en het faillissement de enige twee gronden zijn die mogelijk voor analoge toepassing in aanmerking komen. ${ }^{50}$ Een rechtspersoon kan niet doodgaan, maar kan wel ophouden te bestaan. Het ligt dan ook voor de hand om het ophouden te bestaan aan te houden als 'moment van overlijden'. ${ }^{51}$ Wij zouden willen aannemen dat het einde van de vertegenwoordigingsbevoegdheid

49. Asser/Kortmann 3-III 2017/33.

50. Hoewel men mogelijk parallellen zou kunnen trekken met surseance van betaling en prepackconstructies bij rechtspersonen, hebben wij ervoor gekozen om hier niet nader op in te gaan, omdat deze figuren niet in art. 3:72 BW worden genoemd.

51. Vgl. G.C. van Eck, in: Commentaar Ondernemingsrecht, Den Haag: Sdu Uitgevers, art. 2:309 BW, aant. 2.3. van de statutaire procuratiehouder in het ondernemingsrecht besloten ligt. De statutaire procuratiehouder baseert zijn of haar vertegenwoordigingsbevoegdheid namelijk op de statuten. Op het moment dat de rechtspersoon ophoudt te bestaan, houden de statuten ook op te bestaan. Dit heeft dan twee gevolgen: (1) de vertegenwoordigingsbevoegdheid van de statutaire procuratiehouder heeft geen grondslag meer; en (2) er is geen vennootschap meer om te vertegenwoordigen.

Ten aanzien van het faillissement is het interessanter. Bestuurders verliezen niet hun bevoegdheid in het faillissement van de vennootschap. ${ }^{52} \mathrm{Wij}$ zouden willen aannemen dat een vergelijking met de bestuurders op dit gebied op zijn plaats is. Wij hebben in paragraaf 2 immers uiteengezet dat een statutaire procuratiehouder een vennootschapsrechtelijke functionaris is en geen gevolmachtigde. Dit maakt dat er geen ruimte bestaat voor analoge toepassing van artikel 3:72 onder a BW ten aanzien van het faillissement.

Sub $b$ is van regelend recht en bepaalt dat de volmacht eindigt in geval van dood, ondercuratelestelling, faillissement of schuldsanering van de gevolmachtigde (bij analoge toepassing dus de statutaire procuratiehouder).

Ten aanzien van de dood van de statutaire procuratiehouder is het de vraag of analoge toepassing van artikel $3: 72$ onder $b$ $\mathrm{BW}$ nodig is. Boek $2 \mathrm{BW}$ bevat geen grond voor het beëindigen van de vertegenwoordigingsbevoegdheid van een statutaire procuratiehouder bij zijn of haar dood, al zullen de statuten hier meestal wel in voorzien. Doen ze dit niet, dan ligt het voor de hand om artikel 3:72 onder b BW analoog toe te passen, indien en voor zover een concrete rechtsgrond nodig is.

Ten aanzien van de ondercuratelestelling zouden wij willen aannemen dat analoge toepassing niet opgaat. Ondercuratelestelling heeft handelingsonbekwaamheid tot gevolg, maar handelingsonbekwaamheid belet niet dat iemand optreedt als gevolmachtigde (art. 3:63 lid 1 BW). Van artikel 3:63 lid 1 BW weten we zeker dat dit analoog van toepassing is op andere vertegenwoordigingsfiguren. ${ }^{53}$ Artikel $3: 72$ onder $b$ BW is van regelend recht. De wetgever was van oordeel dat - hoewel ondercuratelestelling niet maakt dat je niet meer namens een ander kunt handelen - ondercuratelestelling dusdanig grote gevolgen heeft voor de positie van de gevolmachtigde dat het uitgangspunt het einde van de volmacht moet inhouden. ${ }^{54}$ Artikel 3:72 BW is echter niet krachtens wet analoog van toepassing. Dit, in combinatie met het feit dat artikel 3:63 lid $1 \mathrm{BW}$ dat wel is én artikel 3:72 onder b BW van regelend recht is, makt ons inziens dat analoge toepassing op de statutaire procuratiehouder niet opgaat. Overigens is deze conclusie ons inziens ook wenselijk: het ligt meer voor de hand om als uitgangspunt te nemen dat de vertegenwoordi-

52. B. Wessels, Gevolgen van faillietverklaring (Wessels Insolventierecht, deel I), Deventer: Wolters Kluwer 2019, p. 169.

53. Dit blijkt uit art. 3:78 BW.

54. Asser/Kortmann 3-III 2017/59. 
gingsbevoegdheid niet eindigt bij ondercuratelestelling, tenzij anders is bepaald in de statuten. ${ }^{55}$ Immers, anders zou een onder curatele gestelde statutair vertegenwoordiger ineens niet meer bevoegd zijn, ook als dit (nog) niet uit de statuten of het handelsregister blijkt.

Ten aanzien van het faillissement van de statutaire procuratiehouder geldt het volgende. Het faillissement ziet slechts op de goederen van de failliet en heeft dus geen effect op de burgerlijke rechten en bevoegdheden van de failliet. Onder de burgerlijke rechten en bevoegdheden valt in ieder geval het vertegenwoordigen van een rechtspersoon als bestuurder. ${ }^{56}$ $\mathrm{Nu}$ de statutaire procuratiehouder net als de bestuurder een vennootschapsrechtelijke functionaris is, vindt artikel 3:72 onder b BW geen analoge toepassing op de statutaire procuratiehouder. Uiteraard kunnen de statuten net als voor een bestuurder bepalen dat de statutaire procuratiehouder defungeert bij zijn faillissement of toepassing van de schuldsanering.

Sub c is van dwingend recht en bepaalt dat de volmacht eindigt in geval van herroeping door de volmachtgever. De basis van de vertegenwoordigingsbevoegdheid van de statutaire procuratiehouder ligt in de statuten besloten en is in het algemeen in sterke mate verweven met het ondernemingsrecht. In dit licht menen wij dat de aard van de bevoegdheid van de statutaire procuratiehouder zich verzet tegen analoge toepassing van artikel 3:72 onder c BW. We sluiten an bij de algemene regels met betrekking tot de benoeming van andere statutaire functionarissen: degene die benoemt, is ook degene die schorst en/of ontslaat. ${ }^{57}$

Sub d is van dwingend recht en bepaalt dat de volmacht eindigt in geval van opzegging door de gevolmachtigde. Wij zien geen bezwaren tegen de analoge toepassing van dit artikel op de statutaire procuratiehouder. Indien de statuten echter bepalen dat bijvoorbeeld iedere commissaris ook statutaire procuratiehouder is, lijkt het ons niet mogelijk alleen de functie van statutaire procuratiehouder op te zeggen. Dat zou immers strijd opleveren met de statuten. In dat geval kan alleen afstand worden gedaan van beide functies.

\subsection{Overige bepalingen}

Artikel 3:73 lid 1 en 2 BW regelen de resterende bevoegdheden van een gevolmachtigde na de dood of ondercuratelestelling van de volmachtgever. Ondercuratelestelling van een rechtspersoon is niet mogelijk. ${ }^{58} \mathrm{Nu}$ de vertegenwoordigde bij een statutaire procuratiehouder altijd een rechtspersoon is,

55. Overigens blijkt uit de parlementaire geschiedenis dat afwijking van art. 3:72 onder b BW ook besloten kan liggen in de volmacht, indien de aard van de volmacht dit vergt. Vgl. Van Zeben \& Du Pon 1981, p. 293-294.

56. HR 24 april 2020, ECLI:NL:HR:2020:801, JIN 2020/97 m.nt. D.S. Volleberg.

57. Overigens is er dan materieel gezien geen verschil met art. 3:72 onder c BW.

58. A.J.M. Nuytinck, Personen- en familierecht, huwelijksvermogensrecht en erfrecht, Deventer: Wolters Kluwer 2018, p. 317 kunnen artikel 3:73 lid 1 en 2 BW wat betreft de ondercuratelestelling niet van toepassing zijn op de statutaire procuratiehouder. Ook wat betreft de dood van de vertegenwoordigde zijn wij van mening dat artikel 3:73 lid 1 en 2 BW niet van toepassing kunnen zijn op de statutaire procuratiehouder, omdat de persoon van de vertegenwoordigde zich daartegen verzet. $\mathrm{Nu}$ artikel 3:73 lid 1 en $2 \mathrm{BW}$ niet analoog van toepassing zijn, kan behandeling van artikel 3:73 lid 3 BW achterwege blijven.

Een volmacht kan onherroepelijk zijn voor zover deze strekt tot het verrichten van een rechtshandeling die in het belang is van de gevolmachtigde of een derde (art. 3:74 lid 1 BW). Tevens kan in dat geval worden bepaald dat de volmacht niet eindigt bij de dood of ondercuratelestelling van de gevolmachtigde. Onherroepelijkheid sluit deze twee uitzonderingen - tenzij anders bepaald - in.

Ten eerste is een onherroepelijke procuratie niet mogelijk. De procuratie staat immers in de statuten van de vennootschap. Het verlenen van een onherroepelijke procuratie zou betekenen dat deze bepaling van de statuten nooit gewijzigd kan worden. Uit de wet volgt dat de wijziging van een bepaling in de statuten altijd mogelijk is met algemene stemmen in een vergadering waarin het gehele geplaatste kapitaal vertegenwoordigd is. ${ }^{59}$

Het voortbestaan van een volmacht in de zin van de artikelen 3:73 lid 1 en 2 en 3:74 lid 1 BW na de dood van een natuurlijk persoon-volmachtgever is alleen mogelijk omdat de wetgever voorziet in de gevolgen van de uitoefening van de volmacht na de dood van de volmachtgever. Artikel 3:77 BW bepaalt voor de natuurlijk persoon namelijk dat een geldig verrichte rechtshandeling na de dood van de volmachtgever de erfgenamen en de wederpartij bindt alsof de rechtshandeling tijdens het leven van de volmachtgever was verricht. ${ }^{60}$

Dit is anders bij de rechtspersoon die na ontbinding is opgehouden te bestaan. Die rechtspersoon heeft vanwege de wettelijke vereffeningsprocedure geen vermogen meer. De wet voorziet niet in een regeling waardoor de beschikkingshandeling aan een ander wordt toegerekend, zoals bij de natuurlijk persoon wel het geval is. Een beschikkingshandeling ten laste van het niet langer bestaande vermogen is daarom niet mogelijk. ${ }^{61}$

Ook de bepaling uit artikel 3:74 lid $1 \mathrm{BW}$ omtrent het voortbestaan van de volmacht na de ondercuratelestelling kan niet

59. Zo blijkt uit art. 2:121/231 lid 3 BW.

60. J.M. Blanco Fernández, Ook na de ontbinding van een rechtspersoon (anders dan door faillissement) kan een door die rechtspersoon verstrekte onherroepelijke volmacht worden gebruik. Reactie op de beantwoording van rechtsvraag 13 in WPNR (2001) 6461 door prof. mr. A.A. van Velten, WPNR 2001, afl. 6467, p. 1006-1007; zie ook Van der Korst, in: GS Vermogensrecht, art. 3:77 BW, aant. 2.

61. Blanco Fernández 2001, p. 1006-1007. 


\section{Maandblad}

Ondernemingsrecht

analoog worden toegepast, omdat een rechtspersoon niet onder curatele gesteld kan worden. ${ }^{62}$

Artikel 3:75 lid $1 \mathrm{BW}$ bepaalt dat de gevolmachtigde bij het einde van de volmacht de stukken waaruit de volmacht blijkt, moet teruggeven aan de volmachtgever, of moet toestaan dat de volmachtgever daarop aantekent dat de volmacht is geëindigd. In het geval van de statutaire procuratiehouder lijkt dit weinig praktisch nut te hebben, omdat de statutaire procuratiehouder wordt ingeschreven (en dus ook uitgeschreven) in het handelsregister. Desondanks zien wij geen bezwaar tegen de analoge toepassing van dit artikellid. Een dergelijke aantekening zou zelfs kunnen helpen indien in een benoemingsbesluit meerdere statutaire procuratiehouders zijn benoemd en één daarvan geen statutaire procuratiehouder meer is. ${ }^{63}$ Immers, ook al is de statutaire procuratiehouder uitgeschreven uit het handelsregister, hij of zij zou een derde alsnog om de tuin kunnen leiden met een dergelijk besluit. Ditzelfde geldt als de statutaire procuratiehouder bij naam in de statuten is genoemd: de notaris kan dan aantekening hiervan maken op de minuut. ${ }^{64}$

Artikel 3:77 BW regelt de gevolgen van de toepassing van de artikelen 3:73 en 3:74 BW in het geval dat de gevolmachtigde een natuurlijk persoon is en overlijdt. ${ }^{65} \mathrm{Nu}$ artikel 3:77 BW specifiek geschreven is voor de natuurlijk persoon als vertegenwoordigde, is het artikel niet toepasbaar op de statutaire procuratiehouder. De vertegenwoordigde is immers altijd een rechtspersoon. De persoon van de vertegenwoordigde verzet zich tegen toepassing van artikel 3:77 BW op de vertegenwoordigingsverhouding tussen de vennootschap en de statutaire procuratiehouder.

\section{Conclusie}

De statutaire procuratiehouder is geen gevolmachtigde, maar een vennootschapsrechtelijke functionaris. Dit blijkt duidelijk uit het systeem van de wet en de bedoeling van de wetgever. Dit heeft bijvoorbeeld tot gevolg dat sprake is van een notariële vertegenwoordigingsbevoegdheid, hetgeen sterker is dan een vertegenwoordigingsbevoegdheid krachtens volmacht. Zo zal bijvoorbeeld geen separate authentieke volmacht vereist zijn voor bepaalde handelingen, zoals het vestigen van een hypotheek (art. 3:260 lid 3 BW), indien sprake is van een statutaire procuratiehouder. ${ }^{66}$ Afhankelijk van de uitleg van artikel 2:130/240 lid 3 BW kan ook een volledig op maat gesne- den vertegenwoordigingsbevoegdheid in het leven worden geroepen, die na inschrijving met al haar beperkingen werkt jegens derden.

In deze bijdrage hebben wij geprobeerd een compleet overzicht te creëren van de analoge toepasbaarheid van ieder artikel(lid) in titel $3.3 \mathrm{BW}$ op de statutaire procuratiehouder. Gebleken is dat een redelijk aantal artikelen uit titel 3.3 BW analoog toepasbaar is op de statutaire procuratiehouder, zonder genoemd te worden in de schakelbepaling. Verrassend zijn onze bevindingen niet. De bepalingen die ons inziens analoog van toepassing zijn, verhouden zich goed tot de verhouding tussen de statutaire procuratiehouder en de vennootschap.

De functionele relevantie van analoge toepasbaarheid ziet vooral op het verschaffen van duidelijkheid in situaties waarin de wet niet voorziet. Zo biedt toepassing van artikel 3:66 lid 2 BW een wettelijke grondslag voor toerekening van kennis van de statutaire procuratiehouder aan de vennootschap, zodat niet volstaan hoeft te worden met het Babbel-criterium. Ook toepassing van artikel 3:61 lid $3 \mathrm{BW}$ (indien je daaraan toekomt) is een belangrijke afwijking van artikel 2:6 lid $4 \mathrm{BW}$.

Bijzonder is hoeveel afhangt van de discussie over de toepasselijkheid van artikel 2:130/240 lid 3 BW op de statutaire procuratiehouder. Indien men van mening is dat deze artikelen niet van toepassing zijn op de statutaire procuratiehouder (en dus niet richtlijnconform uitlegt), zijn de artikelen 3:62 lid 1 en 2, 3:64, 3:65 én 3:68 BW aanvullend analoog toepasbaar. Met analoge toepassing van deze bepalingen kan het karakter van de statutaire procuratie dus substantieel anders worden. Wij denken dat het nuttig zou zijn dat op dit punt verdere gedachtevorming plaats zou vinden, en nemen ons voor daar zelf ook actief aan bij te dragen.

Voor praktische redenen worden onze bevindingen hieronder nog eens in tabel 1 samengevat.

62. Nu art. 3:74 lid $1 \mathrm{BW}$ niet van toepassing is, kan de behandeling van art. 3:74 lid $2 \mathrm{t} / \mathrm{m} 4 \mathrm{BW}$ achterwege blijven. Deze leden bevatten een nadere uitwerking van de in art. 3:74 lid $1 \mathrm{BW}$ genoemde volmacht die niet eindigt bij de dood of ondercuratelestelling van de volmachtgever, dan wel onherroepelijk is.

63. Van Zeben \& Du Pon 1981, p. 296 (MvA II).

64. Vermoedelijk staat de procuratiehouder in dat geval nog wel steeds vermeld in de statuten zoals deze zijn gedeponeerd bij het handelsregister, daar geen statutenwijziging heeft plaatsgevonden. Wij verwachten echter dat de notaris zonder problemen de pagina waarop de aantekening is gemaakt, kan scannen en bij het handelsregister kan uploaden.

65. Van der Korst, in: GS Vermogensrecht, art. 3:77 BW, aant. 2.

66. Groffen 1995, p. 84. 


\section{Maandblad}

Ondernemingsrecht

Tabel 1 Overzicht

Analoog toepasbaar Analoog toepasbaar Niet analoog toepas- Hangt af van uitleg

krachtens art. 3:78 $\mathrm{BW}$ zonder art. 3:78 $\mathrm{BW}$ art. 2:130/240 lid $3 \mathrm{BW}$

Art. 3:60 lid $1 \mathrm{BW}$

Art. 3:60 lid 2 BW

$\mathrm{x}$

Art. 3:61 lid $1 \mathrm{BW}$ baar

(2.

Art. 3:61 lid 2 BW

Art. 3:61 lid 3 BW

Art. 3:62 lid 1 BW

$\mathrm{x}$

Art. 3:62 lid 2 BW

Art. 3:63 lid 1 BW

Art. 3:63 lid 2 BW

Art. 3:64 BW

Art. 3:65 BW

Art. 3:66 lid 1 BW $\quad x$

Art. 3:66 lid 2 BW

$\mathrm{x}$

Art. 3:67 lid 1 en 2 BW $\quad x$

Art. 3:68 BW

Art. 3:69 lid $1 \mathrm{t} / \mathrm{m} 5$ BW $\quad x$

Art. 3:70 BW

Art. 3:71 lid 1 en 2 BW

Art. 3:72 onder a BW

Art. 3:72 onder b BW

gedeeltelijk

Art. 3:72 onder c BW

Art. 3:72 onder d BW

$\mathrm{x}$

Art. 3:73 lid $1 \mathrm{BW}$

Art. 3:73 lid 2 BW

Art. 3:73 lid 3 BW

Art. 3:74 lid 1 BW

Art. 3:74 lid 2 BW

Art. 3:74 lid 3 BW

Art. 3:74 lid 4 BW

$\mathrm{x}$
$\mathrm{x}$
$\mathrm{x}$
$\mathrm{x}$
$\mathrm{x}$
$\mathrm{x}$
$\mathrm{x}$
gedeeltelijk

$\mathrm{x}$
$\mathrm{x}$

Art. 3:75 lid $1 \mathrm{BW}$

Art. 3:76 lid 1 BW

Art. 3:76 lid 2 BW

$\mathrm{X}$ 